\title{
Diversity dynamics operating between students, lecturers and management in a historically Black university: The lecturers' perspective
}

\begin{abstract}
Author:
Michelle S. May ${ }^{1}$

Affiliation:

${ }^{1}$ Department of Industrial and Organisational

Psychology, University of

South Africa, South Africa

Correspondence to:

Michelle May

Email:

mayms@unisa.ac.za

Postal address:

PO Box 392, UNISA 0003,

South Africa

Dates:

Received: 01 July 2011

Accepted: 11 Jan. 2012

Published: 27 Mar. 2012

How to cite this article: May, M.S. (2012). Diversity dynamics operating between students, lecturers and management in a historically Black university: The lecturers' perspective. SA Journal of Industrial Psychology/SA Tydskrif vir Bedryfsielkunde, 38(2), Art. \#1003, 8 pages. http:// dx.doi.org/10.4102/sajip. v38i2.1003
\end{abstract}

Orientation: The historically Black and White universities in South Africa were shaped by apartheid policies (Abdi, 2003). This research project started, within this socio-political context, because lecturers in a historically Black university (HBU) were confronted with unresolved experiences concerning their relationship with students and management. The researcher describes the diversity dynamics in a historically Black university, by forming an in-depth understanding of these dynamics, operating in the relationship between the students, lecturers and management, from the systems psychodynamic perspective.

Research purpose: The purpose of the research was to describe the experiences of nine lecturers in a particular HBU. This was undertaken to analyse and interpret the conscious and unconscious diversity dynamics operating in the relationship between the students, lecturers and management, from the lecturers' perspective.

Motivation for the study: The researcher was interested in the nature of the diversity dynamics operating in the relationship between students, lecturers and management in an HBU, as a platform towards understanding diversity dynamics in educational institutions and South African organisations.

Research design, approach and method: Qualitative and descriptive research approaches were used. Hermeneutic phenomenology, using the systems psychodynamic perspective, allowed for the description and interpretation of diversity dynamics operating in the relationship between the students, lecturers and management. The data were obtained through in-depth interviews with nine lecturers. Thematic analysis resulted in two broad themes for which a discussion was provided and a research hypothesis formulated.

Main findings: Two broad themes manifested, firstly diversity characteristics and secondly struggle skills entrenching the Black and White divide.

Practical/managerial implications: The research highlighted the importance of understanding the diversity dynamics operating in the relationship between students, lecturers and management. This was in order to develop our understanding of diversity dynamics operating in educational institutions specifically, and organisations in general.

Contribution/value-add: The understanding about diversity dynamics is available for application, by lecturers and management, to form a different understanding of conscious and unconscious factors impacting on the relationship between the three stakeholders, and subsequently the effectiveness of the three stakeholders in their respective roles. This understanding can also be transferred to other organisations.

\section{Introduction}

Tertiary education in South Africa had as its main purpose, during apartheid, to maintain and reproduce, through legislative and other measures, apartheid's social order - a social order in which tertiary education was reserved for an elite few (Winburg, 2004). Based on this, I propose that current South African university life is inextricably linked with the apartheid past. Ruth (2000, p. 18) eloquently illustrated this point when stating that 'entrenched historical legacies [exist] as undercurrents in the life of [the university] long after persistent efforts and explicit change have won the day.' It is evident that educational and economic inequality, prolonged over 300 years, cannot be totally addressed within the foreseeable future, through the single co-ordinated system of education and training, regardless of numerous attempts by government, since 1994, to reform the education system and the mergers between historically Black universities (HBUs) and historically White universities (HWUs) in 2004 (Abdi, 2003; Kraak, 2004; Robus \& Macleod, 2006). Therefore, the themes and discourses, which come with centuries of marginalisation of Black 
people at the hands of White people, serve as the backdrop to this historical research about the diversity dynamics that operated in the HBU.

The awareness of the diversity dynamics that operated in the HBU can be developed, by describing the diversity dynamics evident in the relationships between the students, lecturers and management, from the lecturers' perspective. This understanding about diversity dynamics can then be used by lecturers and management, to form a different understanding of conscious and unconscious factors impacting on the relationship between the three stakeholders, and subsequently the effectiveness of the three stakeholders in their respective roles. This understanding of diversity dynamics can also be transferred to other South African organisations, enhancing the understanding of diversity dynamics and informing diversity management initiatives implemented in these organisations.

\section{The historical landscape of South African universities}

Through extension of the Universities Education Act (No. 45 of 1959), the first phase in the establishment of HBUs, as separate universities for Black students, commenced, and restricted the admission of Black people to HWUs. Importantly these universities were racially and ethnically divided for eight Black ethnic groups, the Coloured and Indian groups (Abdi, 2003; Robus \& Macleod, 2006; Ruth, 2000). Although Black university colleges were proclaimed autonomous in 1969 by Acts of Parliament, these universities remained White-controlled Black universities (Starfield, 2002). This points to the paradoxical nature of HBUs in which power and authority resided with White people, whilst Black people occupied advisory and token positions, and in this way the power relations between Black and White people was maintained (Mabokela, 2001). The White, and mainly Afrikaner, management and lecturers were also considered to be collaborating with government, such as the South African or independent homeland government, resulting in protracted conflict between students, lecturers and management (Sumbulu \& Boswell, 2003). At this time, the Black lecturers were probably too few to impact on the students and the status quo (Ndebele, 1997).

The HBUs became one of the many sites of struggle against the apartheid regime (Ruth, 2000), owing to a deteriorating education system and the lack of economic opportunities for young Black graduates during the 1970s and 1980s. The Soweto uprising of 1976 ensured that the educational institutions (high schools and HBUs) became an important site of struggle, for the youth, over educational and also broader political, issues (Nkomo, 1990). This transformed education and HBUs into ungovernable war zones where students expressed their dissatisfaction through unruly and, at times, violent behaviour to which the police and army reacted with military force (Ruth, 2000).

\section{The systems psychodynamic perspective}

Systems psychodynamics (SP) allows for the study and interpretation of collective, interdependent unconscious and conscious individual, group and intergroup processes, resulting from the interconnection between different groups and subgroups within a social system (Czander \& Eisold, 2003; Neumann, 1999). It affords us the opportunity to attend to unconscious phenomena within people, the organisational context (tasks, structures, boundaries) and the complex interaction between the two (Amado, 1995; Nutkevich, 1998). In diversity dynamics the theoretical underpinnings of SP are applied to understand the psychodynamics which occur in the context of difference and similarities amongst people (Cilliers \& May, 2002; May \& Evans, 2004; Pretorius, 2003).

\section{Diversity dynamics}

Diversity dynamics is a relational phenomenon through which individuals, across differences and similarities, make certain assumptions about others. The individuals then behave, on both a conscious and unconscious level, in a particular way towards each other, based on these differences and similarities (Pretorius, 2003). The defense mechanisms, splitting-projection-introjection-projective identification, underlie these diversity dynamics. Splitting, based on the primary and secondary dimensions of diversity, enables us to divide the world into good and bad, Black and White, the oppressed and the oppressor (Skolnick \& Greene, 2004). It is an inherent need in groups to split self from others because it provides the opportunity to dump the bad onto another group, in order to maintain the good within the group (May \& Evans, 2004; Skolnick \& Greene, 2004).

Introjection and projection are used simultaneously through the process of splitting. Introjection involves attributing positive aspects to one's group and refusing to deal with negative aspects, and externalising the negative aspects of one's group. Thus, introjection manifests when group members internalise positive and preferred characteristics, such as competence, superiority, the establishment of closeness to and a constant presence with the positive. Projection involves attributing negative aspects to other groups by rejecting and externalising negative aspects of one's own group. In this way a group can eradicate bad characteristics, such as incompetence and inferiority (Cilliers \& May, 2002). By introjecting the positive feelings and projecting the negative feelings a group produces and maintains 'illusory goodness and self-idealisation.' The other group, identifying with the projection, then becomes the denigrated one, such as the container for the unacceptable and rejected parts of the group that idealises itself (Skolnick \& Greene, 2004). Through defense mechanisms, such as splitting, introjections, projection and projective identification, groups in the intergroup process project their unacceptable, disavowed, unexpressed and undiscussible aspects into the other groups. This is performed in order to preserve a good and idealised version of themselves operating in the paranoid-schizoid position (Klein, 1985). 
Several authors have proposed that envy is a destructive phenomenon in groups, organisations and society (Mouly \& Sankaram, 2002; Stein, 2000). With envy, the other individual or group is attacked through spoiling or destroying (Hiles, 2007). Envy is stimulated in situations where dependency and helplessness are experienced, for example situations of disparity in resources, actual deprivation and the lack of provision of satisfying experiences (Stein, 2000). Across differences, an envious attack can be directed at other groups.

Groups experience a shift from the paranoid-schizoid to the depressive position, by re-owning their projections and reducing splitting, polarisation, introjections, projection and projective identification. In the depressive position groups realise that they and other groups contain both good and bad parts - resulting in more effective relationships across differences. Groups oscillate between a depressive, intersubjective position of functioning and a more primitive ego-centric paranoid-schizoid position (Klein, 1985).

The core research problem was formulated as follows: What were the diversity dynamics operating in the relationship between students, lecturers and management at an HBU? Researchers have not explored the diversity dynamics that operated in the relationship between the students, lecturers and management in a South African HBU. As a lecturer who worked at an HBU, I am interested in understanding the nature of the diversity dynamics evident in the relationship between the students, lecturers and management, and how these dynamics impacted the effectiveness of these three stakeholders in their different roles. By describing the diversity dynamics evident in their relationships from the lecturers' perspective, the awareness of the diversity dynamics that operated in the HBU can be developed.

The potential value-add of the research is achieved by enhancing the understanding of diversity dynamics. It is also available for application by lecturers and management, to form a different understanding of conscious and unconscious factors impacting on the relationship between, and effectiveness of, the three stakeholders in their respective roles. This understanding of diversity dynamics can be used in other South African organisations by researchers, consultants and managers to enhance their understanding of diversity dynamics, and inform the nature of the diversity management initiatives implemented in these organisations.

The rest of the article is structured as follows. The research design is presented, with reference to the research approach and strategy. This is followed by the research method consisting of the setting, roles of the researcher, sampling method, data collection, recording and analysis. Lastly, the strategies employed to ensure quality data are mentioned. Thereafter the findings are presented as manifested themes. The discussion contains the research hypothesis followed by the conclusion, recommendations, limitations and suggestions for further research.

\section{Research design Research approach}

A qualitative research method was followed, based on hermeneutic phenomenology (Terre Blanche \& Durrheim, 2002), that allowed for in-depth description and interpretation, and that applied the SP perspective of the essence of the lecturers' (emotional) experiences in an HBU. This SP perspective enabled the formation of an indepth understanding of the diversity dynamics operating in the relationship between the students, lecturers and management.

\section{Research strategy}

Using a case study design, I obtained an in-depth description of the (emotional) experiences of the lecturers, with emphasis on the diversity dynamics at work in their relationship with students and management. A literature review was undertaken at the beginning of the research process and was used as an ongoing strategy during the research process, to focus on different elements of the research, in order to establish a sound thread of reference pertaining to the key arguments and ideas. This strategy is especially applicable when applied to the literature control that will be used in the interpretation of the data (Creswell, 2003; Henning, Van Rensburg \& Smit, 2004).

\section{Research method}

\section{Research setting}

The research process started when I, as a lecturer at an HBU, was confronted by violent interactions between lecturers and students, and perceived a passivity from management when lecturers were violently threatened by students in social and academic settings, within the HBU. Based on sociohistorical factors, my personal experiences and SP, I explored the (emotional) experiences of lecturers at an HBU, such as their relationship with students and management, to form an understanding about the diversity dynamics operating between the students, lecturers and management.

\section{Sample and sampling}

Based on the work of Endacott (2005), a convenience sample, consisting of nine lecturers from a specific department in an HBU, was used to participate in in-depth interviews. I chose these lecturers because I once formed part of their department, and the lecturers were willing and available to participate in the research topic, which they could discuss eloquently. The biographical information of the sample is provided in Table 1.

\section{Data collection methods}

As suggested by Terre Blanche and Durrheim (2002) the purpose of the data collected was to obtain an in-depth understanding of the lecturers' experiences of their work context. This was achieved through in-depth interviews which started with a single open-ended question, viz. 'Please 
TABLE 1: Biographical information of the sample.

\begin{tabular}{llll}
\hline Race & Gender & Position & Age \\
\hline White $(n=8)$ & Female $(n=6)$ & $\begin{array}{l}\text { Management and } \\
\text { senior lecturer }(n=1) \\
\text { Senior lecturer }(n=1) \\
\text { Lecturer }(n=4)\end{array}$ & $\begin{array}{l}\text { Above 40 }(n=2) \\
\text { Between 30 and 40 }(n=1) \\
\text { Below 30 }(n=3)\end{array}$ \\
& Male $(n=2)$ & $\begin{array}{l}\text { Senior lecturer }(n=1) \\
\text { Lecturer }(n=1)\end{array}$ & $\begin{array}{l}\text { Between 30 and 40 }(n=1) \\
\text { Below 30 }(n=1)\end{array}$ \\
& Lecturer $(n=1)$ & Below 30 $(n=1)$ \\
\hline Black $(n=1)$ & Male $(n=1)$ & Len
\end{tabular}

$n$, number.

tell me the story of your experiences as a lecturer at this university'. Questions based on what the lecturers were saying were generated thereafter. Through the questions I explored the nature of diversity evident in the relationship between the three stakeholders.

\section{Recording of data}

The in-depth interviews were recorded and the nine audiotape recordings were transcribed verbatim, as suggested by Terre Blanche and Durrheim (2002). The electronic versions of data and the audiotapes were securely stored and managed.

\section{Data analyses and interpretation}

Data analyses entailed transcribing the interviews, familiarising myself with voluminous amounts of data, categorising and coding the data and eliciting themes from the data (see Terre Blanche \& Durrheim, 2002). In the analysis, interpretation and reporting of the findings I used the interpretive stance as proposed by Shapiro and Carr (1991). I interpreted data based on evidence from the data, existing literature about SP and the self as instrument (Schafer, 2003).

\section{Strategies employed to ensure quality data}

The plausibility, truth value and transferability of the analysed research were negotiated with the lecturers and certain experts in the SP field. From reading the analysis and interpretation of the data they reported that they considered the analysis and interpretation to be plausible. In this article, I attempted to provide a clear description of the sampling, data collected, data analysed and interpretation whilst explicating an account of the experiences of the lecturers at the HBU. Through this account the reader was free to decide about the validity of this project, whether or not she or he would be able to replicate (reliability) the research, and would it be possible to transfer these findings to his or her context (Cresswell, 2003; Henning et al., 2004; Terre Blanche and Durrheim, 2002)?

Informed consent was obtained from the lecturers by describing the project and explaining that the data will be interpreted from the SP lens (Christians, 2005). The lecturers' confidentiality and anonymity were ensured by storing the audio-tapes and transcripts of the data safely. As suggested by Christians (2005), the lecturers' identities were further protected by excluding certain identifying aspects from the data.

\section{Reporting}

Each theme is discussed by providing verbatim evidence from the lecturers. Then each theme is discussed by integrating the theme with existing literature. Then two research hypotheses based on the integration of each theme with literature were presented.

\section{Findings}

In order to illustrate the diversity dynamics operating in the $\mathrm{HBU}$, two themes, about the diversity characteristics and struggle skills entrenching the Black and White divide, were evident.

\section{Diversity characteristics entrenching the Black and White divide}

Given that lecturers, who in this sample are mainly White, the three stakeholders can be divided into particular racial groupings - Black students, White lecturers and Black management. Although the lecturers did not directly refer to the racial groupings in the $\mathrm{HBU}$, the importance of race in the transactions between students, lecturers and management was inferred from the lecturers' statements.

Several lecturers commented that issues pertaining to race affected their relationships with the (Black) students and management. The following statements illustrate this. L4 stated that:

'by virtue of being an academic institution there is a gap between students and academic staff. It has always been a bit worse at Black universities because the academic staff used to be mainly White...' (Lecturer 4, lecturer at historically Black university)

L7 affirmed that:

'the fact that you are White is an issue or a potential issue [for the students and management].' (Lecturer 7, lecturer at historically Black university)

It is also important to recognise that the accusations of lecturers being racist were usually experienced when the students were part of a bigger group. L3 expressed that:

'[she] sees them individually or in very small groups, ... all [the accusations] fall away and there's still a real relationship. She continued to say that [the accusations] only come into play when they're in masses and then suddenly even the individual relationships, which I've had with people, I realise I'm not [myself] to them.' (Lecturer 3, lecturer at historically Black university)

Lecturers seemed aware that the students considered them to be racist, especially in the context of the lack of achievement on the part of the students. L2 voiced that:

'we get direct, not even implied, accusations that we are busy disadvantaging the students.' (Lecturer 2, lecturer at historically Black university)

L6 also stated that the old frame of reference that she saw in her relationship with the students was that:

'White people actively, productively, intentionally try to keep Black people down.' (Lecturer 6, lecturer at historically Black university) 
Lecturers reported that they were accused by stakeholders, including the students, who stated that the department is the Vlakplaas $^{1}$ of the university. L2 highlighted that:

'we are compared with Vlakplaas and the old regime and we are a White department, and so on ... we don't care about the students ... and we manipulate the marks'. (Lecturer 2, lecturer at historically Black university)

The projection that lecturers were the students' enemy is also reflected in the statement made by L6 who referred to being seen as a representative of the far-right, White Afrikaner group, she stated 'I feel that I'm actually there as a kind of representative of the right-wing Afrikaners who tried to stop Black people from getting on in life.'

Race also carried potent historical meaning for the relationship between management and lecturers. L4 articulated that:

'some of these people in the management positions used to be students or junior staff members [or new appointments, mainly Affirmative Action] and they were part of the struggle against the previous management system'. (Lecturer 4, lecturer at historically Black university)

This socio-political power was further entrenched by the positional authority afforded management in the HBU. It is possible that the mainly White lecturers were unconsciously influenced by a question around whether or not Black management was capable of leading them, of whom some were past students in the department, or the lecturers' junior colleagues, or were perceived as affirmative action appointees. Although management was not asked, it is suggested that perhaps the unconscious question that influenced management, based on their behaviour, was whether they, as Black management, can manage and lead White lecturers or not.

In a conflictual situation involving students, lecturers and management, two of the lecturers attempted to reveal themselves as multifaceted human beings who suggested their personal experience of the plight of the students. L3 echoed a story of one student who said 'what a struggle it had been for him to come so many miles to university, away from home, his parents were struggling to pay'. She responded to this story by telling him that she did not study at university immediately after leaving school, and challenged the students' perceptions that 'just because we've got White skins or whatever, ... we haven't necessarily had it all easy. [Students] never even responded to the story ... somehow there were no responses.'

It seemed that issues pertaining to race did not alone influence the student-lecturer-management relationship, but also issues of power and positional authority. L2 stated that:

'perhaps it is not just about White and Black; it's about someone who has power and someone who has no power. Someone who has knowledge and someone who has no knowledge.' (Lecturer 2, lecturer at historically Black university)

1.Vlakplaas was the farm where the death squads of the apartheid security forces were based.

\section{L4 articulated that:}

'mixed up with that [the fact that lecturers are part of the old system] is the thing that [lecturers] have the authority to give marks and somehow these things always get mixed up'. She continued to say that 'the academic authority and the old political thing I think are to a large extent still not separate.' (Lecturer 4, lecturer at historically Black university)

Another possible diversity characteristic is the language difficulties of the students as observed in their assignments, tests and examinations. Then there are the cultural and assumed political differences between the students and lecturers. Given that the students lived in townships and the lecturers lived mostly in more affluent suburbs, this points to socio-economic circumstances impacting on the relationship between students and lecturers. Additionally the lecturers may have held different perceptions from the students about how individuals at university should behave. The difference between the lecturers' and students' understanding of appropriate behaviour was accentuated by L2 and L7. L2 stated that "we [the lecturers] possibly have backgrounds at universities where there was a happy atmosphere and a positive educational relationship with the academic staff.' Management to some extent share race, cultural and a particular aspect of the socio-political history with the students. Therefore, these diversity characteristics also widen the divide between lecturers and the management.

\section{Struggle skills entrenching the Black and White divide}

Most of the lecturers also indicated that students tend to use struggle skills from the old political dispensation in the current context. This is affirmed by L5 who stated that 'they still want to struggle, they want to fight, they want to continue with those old skills that they were so good at.'

\section{L4 commented that:}

'the person is usually White (the lecturer) and that person is usually in a position of authority, that person has the power. And you are the victim and through the years you basically developed a way of challenging this very effectively and somehow it is as though people cannot let go of that.' (Lecturer 4, lecturer at historically Black university)

The link between the struggle skills and the developmental process of rebelling against authority should not be overlooked (Coren, 1997). The latter is highlighted by L7 who stated 'that's what we expect from students - we were like that as well.' The above statements also raise the question whether or not the White lecturers had the new skills needed to interact with the Black students. Thus, lecturers told the story about the students using old skills, as if the lecturers had the new skills (conscious and unconscious) for the new dispensation. Of particular importance is that lecturers might have experienced powerlessness in their interactions between the three stakeholders. This idea is eloquently captured by L6 who stated that:

'in my experience it is very difficult for someone with a White skin to voice a protest, because it is not seen as legitimate. If the system does not see you as a legitimate voice it is very difficult to do anything.' (Lecturer 6, lecturer at historically Black university) 
The relationship in the triad was influenced by the different diversity characteristics and the concomitant power and authority that the students ascribed to the lecturers and management. These were based on the diversity characteristics, specifically the power that comes with one's race, the authority and power that comes with one's cultural group and the authority and power linked to one's position. It also seemed that through the process where students ascribed the power and authority either to lecturers or management, students were inevitably forming alliances with either lecturers or management, depending on whom they considered could ensure their academic achievement. Students sporadically formed alliances with lecturers or management, which might suggest that students either empowered or disempowered management and lecturers in the HBU.

It may be that students ascribed to lecturers the historical power and authority as members of the White race group, whereas the lecturers tried to operate in accordance with their current positional authority and power within the system. L2 expressed that:

'in his experience the really bad part is that on the one hand we feel disempowered and on the other hand the students see us as having far more power than we really have.' (Lecturer 2, lecturer at historically Black university)

Certain statements from L4 also seem to indicate that in the same situation, different diversity characteristics could be used simultaneously by students and management to form alliances with each other, against lecturers, and in this way ascribe or strip a group of power and authority. L4 stated that:

'so what [the manager] did was to join with the students against me ... he said to me as a White person I will never understand how this works. Because from their [Black people's] perspective the lecturer is like a mother to the students and she should take responsibility even though it is somebody else's fault'. (Lecturer 4, lecturer at historically Black university)

This statement provides evidence about management seeking an alliance with students by disempowering lecturers. It also illustrates how management accuse White people of not understanding Black people - consequently the implication could be that (White) lecturers do not understand the (Black) students and management. There is an expectation that the lecturers hold the power and authority to assist students, and simultaneously they are stripped of this power and authority.

\section{Discussion}

The purpose of the research was to describe diversity dynamics operating in an HBU by forming an in-depth understanding of these dynamics operating in the relationship between the students, lecturers and management from the SP perspective.

This research was seen as important to enlighten present and future developments pertaining to diversity dynamics operating in the relationship between students, lecturers and management, and also tertiary institutions and organisations in general.
Two manifesting themes were evident in the data, the diversity characteristics entrenching the Black and White divide and struggle skills entrenching the Black and White divide. These themes were interpreted in the context of existing literature about SP, to form new insights about diversity dynamics. Based on these insights two research hypotheses were presented.

It seems that the diversity dynamics operating in the relationship between the students, lecturers and management was entrenched by diversity characteristics. It also seems that the relationship between students, lecturers and management was buried in different layers of difference (race, power, authority, culture, socio-political aspects and language) amplifying the split, between the three stakeholders. Pretorius (2003) and Skolnick and Green (2004) discuss in detail how these diversity characteristics are used to project denigrated parts onto a group, in this case the lecturers, across the divide amplified by diversity characteristics. It is proposed that these lecturers then introject these parts and through projective identification behave in accordance with these denigrated, disavowed parts, whereas the students and management probably hold onto the idealised parts. It seems that the relationship between the stakeholders mainly occurred within the paranoid-schizoid position (see Diamond \& Allcorn, 2003; Jaques, 1990; Klein, 1985; Menzies Lyth, 1990). The projection of denigrated, disavowed and idealised parts is probably an attempt at a reversal of unconscious roles - in the past the denigrated parts and inferiority were projected onto Black people and the idealised parts and superiority were projected onto White people (Powell Pruitt, 2004; Powell Pruitt \& Barber, 2004; Skolnick \& Green, 2004).

It appears that the conscious feelings, namely of feeling disempowered, baffled, disqualified, hurt and negated, experienced by the lecturers in the face of the accusations of racism by students, might attest to their sense of being denigrated by the (Black) students and management (see Pretorius, 2003; Skolnick \& Green, 2004). The lecturers probably also experienced that the students and management, by projecting a racist identity onto them, perceived them to continue the racism and discrimination of the apartheid regime, specifically as the Vlakplaas of the university, against the (Black) students and management. Now, it appears that the lecturers, and consequently the students and management, were kept in particular, unconscious roles.

Juxtaposed against the unconscious attempts to renegotiate unconscious roles amongst the stakeholders, were unconscious efforts to entrench other aspects of these historical roles, which is (White) lecturers as the oppressors and (Black) students and management as the oppressed. In the new dispensation the hierarchical position based on race had, to some extent, changed, resulting in a renegotiation of the hierarchical position of the race groups on a conscious and unconscious level. This apparent reversal, in unconscious roles, amongst the race group might have resulted in groups experiencing changes in the nature of available receptacles for projection of idealized and denigrated parts, across a 
particular diversity divide, in particular race. On another level it seems that attempts were made to entrench historical, unconscious roles holding on to relatedness linked to the White-person-in-the-mind and the Black-person-in-themind. Although the socio-political dispensation has changed, in the South African psyche there is still investment in the relatedness that the different race groups hold towards each other.

In this way the stakeholders unconsciously held onto the White-person-in-the-mind (the racist, the oppressor, the one withholding progress from the Black person) and the Black-person-in-the-mind (the victim, the oppressed, the one who cannot progress). It is proposed that this particular description of the lecturers can be linked to the concept, theWhite-person-in-the-mind. Based on the work about the organisation-in-the-mind (Armstrong, 2006; Young, 1995), the White-person-in-the-mind refers to the relatedness that all South Africans have to a White person. Based on the work of Erlich (2001) and Miller (1989) the relatedness of the students and management towards the lecturers denotes how the lecturers are viewed and treated in terms of their group membership.

Based on the above discussion the following research hypothesis was formulated: It seems that the (White) personin-the-mind of the (Black) students and management is different from how the (White) lecturers see themselves. In the same way the (Black) person-in-the-mind of the (White) lecturers, is possibly different from how the students and management see themselves. This would suggest that diversity dynamics are entrenched by the relatedness, based on diversity characteristics, amongst the (Black) students and management on the one hand and the (White) lecturers on the other. It is also proposed, using the concept, person-inthe-mind, that the stakeholders probably held onto familiar unconscious relatedness, whilst exploring new conscious relationships and unconscious relatedness across diversity characteristics.

It seems that the diversity dynamics operating in the relationship between the students, lecturers and management was further entrenched by the struggle skills of the students. Perhaps students not only participated in a struggle to ensure that they achieved better academic results, but they did so because they may have felt consciously and unconsciously uncertain about whether or not the lecturers or management were the most powerful stakeholder in the university, which would ensure their academic success. The questions which emerge now and remain unclear, are, when, during the struggle in the new political dispensation, did the students use diversity characteristics to ascribe power and authority to lecturers and management, and which of these characteristics did they use? Perhaps what was not being recognised is that the challenge or threat, by using struggle skills, was a way, which Black students knew, to interact with White lecturers.
This challenge or threat seemed to be most prevalent in the test, examination and evaluation situations as indicated by all the lecturers. It is proposed that a situation, in which the students' competence is evaluated, is perhaps the moment of the Black students' most extreme vulnerability, and the White lecturers' highest level of power and authority. This possibly indicates reciprocal splitting between Black students and White lecturers, which provides further evidence to the possibility that the students and lecturers are operating within the paranoid-schizoid position (Klein, 1985). The challenge or threat was probably an indication of Black students projecting badness onto the White lecturers, resulting in a challenge or threat. Thus, the students attacked the lecturers before the lecturers could attack them.

Furthermore, envy probably underlay conflict (see Hiles, 2007; Mouly \& Sankaram, 2002; Stein, 2000) within the HBU and allowed for interaction that was attacking, and not only defensive, between students, lecturers and management. The envious attack may result from desiring that which is perceived to be good and desirable - bear in mind that historically White people were considered the desired ones. Perhaps in the HBU Black students and management were envied because of their perceived privileged position in the new dispensation. In this way envy can be used as a deeply damaging attack on linking (connecting) (Stein, 2000) between the students and management on the one hand and the lecturers on the other, and in this way entrench and maintain the Black and White divide, and consequently the diversity dynamics, between the stakeholders. This deeply damaging, envious attack on linking is further entrenched by the sophisticated use of diversity characteristics to maintain the dynamics operating in the paranoid-schizoid position, making the move to the depressive position almost impossible (Hiles, 2007; Mouly \& Sankaram, 2002; Stein, 2000).

Based on the above discussion the following research hypothesis was formulated: It seems that envy was used in the struggle between the three stakeholders, resulting in a deeply damaging attack on linking, and in this way it entrenched and maintained the Black and White divide, and consequently the diversity dynamics, between the stakeholders. This deeply damaging, envious attack on linking, between the stakeholders, is further entrenched by the sophisticated use of diversity characteristics, which ensured that the stakeholders operated in the paranoidschizoid position, making the move to the depressive position almost impossible.

Through the explication of the themes, and also the presentation of research hypotheses presented, I offered to those, in educational institutions and other organisations, the opportunity to reflect on the diversity dynamics that might be operating in particular organisations, and question how employees possibly collude with these diversity dynamics. 
By exploring the diversity dynamics from the lecturers' perspective, several aspects of diversity dynamics that operated in the HBU emerged. Thus, the stakeholders in the different organisations are confronted with the idea that they are not only involved in their daily (primary) conscious tasks, but in other activities. They are also not innocent bystanders of the diversity dynamics operating in their organisations. They are additionally actively involved in the diversity dynamics, which include constructive and destructive elements, of their organisations. What is particularly important and challenging is the need for stakeholders in universities, in education in general, and in other organisations in South Africa, to attend to the diversity dynamics in organisations. This can be performed through internal work and safe spaces for shared reflection, in order to ensure real and meaningful work relationships.

A limitation of the research is the extent to which my transference and counter transference to the data could have influenced the outcome of the research project. Thus, the self as instrument that assisted in working with data, may also have prevented me from seeing other salient aspects of the lecturers' experiences. However, my willingness to work with transference and counter-transference, also provided an opportunity for in-depth analysis of data.

Future research could focus on current diversity dynamics evident in South African universities amongst students, lecturers and management. Similar research projects can be implemented with organisational consultants working with diversity management, managers and other employees in various organisations. The way in which, and to what extent, diversity dynamics in the South African organisations might have changed, can also be explored to broaden our theoretical and practical understanding of diversity dynamics in organisations.

\section{Acknowledgement Competing interests}

The author declares that she has no financial or personal relationship(s) which may have inappropriately influenced her in writing this paper.

\section{References}

Abdi, A.A. (2003). Apartheid and education in South Africa: Select historical analyses. Western Journal of Black Studies, 27(2), 89-97.

Amado, G. (1995). Why psychoanalytical knowledge helps us understand organisations, A discussion with Elliot Jaques. Human Relations, 48(4), 351-358. http://dx.doi.org/10.1177/001872679504800402

Christians, C.G. (2005). Ethics and politics in qualitative research. In N.K. Denzin \& Y.S. Lincoln (Eds.), The Sage handbook of qualitative research. (3rd edn., pp. 139164). London: SAGE Publications.

Cilliers, F., \& May, M.S. (2002). South African Diversity Dynamics. Reporting on the 2000 Robben Island Diversity Experience. A Group Relations Event. South African Journal of Labour Relations, 26(3), 42-68.

Coren, A. (1997). A Psychodynamic Approach to Education. London: Sheldon.

Creswell, J.W. (2003). Research design: Qualitative, quantitative and mixed methods approaches. (2nd edn.). London: SAGE Publications.

Czander, W., \& Eisold, K. (2003). Psychoanalytic perspectives on organisational consulting: Transference and countertransference. Human Relations, 56(4), 475490. $\mathrm{http}: / / \mathrm{dx}$.doi.org/10.1177/0018726703056004004

Diamond, M., \& Allcorn, S. (2003). The cornerstone of psychoanalytic analysis: Psychological reality, transference and countertransference in the workplace. Human Relations, 56(4), 491-514. http://dx.doi. org/10.1177/0018726703056004005
Endacott, R. (2005). Clinical research 4: Qualitative data collection and analysis. Intensive and Critical Care Nursing, 21(2), 123-127.http://dx.doi.org/10.1016/j. iccn.2004.10.001, PMid:15778077

Erlich, H.S. (2001). Enemies within and without: Paranoia and regression in groups and organisations. In L.J. Gould, L.F. Stapley \& M. Stein (Eds.), The systems psychodynamics of organisations: Integrating the group relations approach, psychoanalytic, and open systems perspective (pp. 115-131). New York: Karnac Books.

Henning, E., Van Rensburg, W., \& Smit, B. (Eds.). (2004). Finding your way in qualitative research. Pretoria: Van Schaik Publishers.

Hiles, D. (2007). Envy, jealousy, greed: A Kleinian approach. Paper presented to Centre for Counselling and Psychotherapy Education, London. Retrieved December 13, 2008, from http://www,psy.dmu.ac.uk/drhiles/ENVYpaperklein.htm

Jaques, E. (1990). On the Dynamics of Social Structure: A contribution to the psychoanalytical study of social phenomena deriving from the views of Melanie Klein. In E. Trist \& H. Murray (Eds.), The social engagement of social science (pp. 420-438). Philadelphia: The University of Pennsylvania Press.

Klein, M. (1985). Our adult world and its roots in infancy. In A.D. Colman \& M.H. Geller (Eds.), Group Relations Reader 2 (pp. 5-19). Washington, DC: A.K. Rice Institute.

Kraak, A. (2004). Discursive tensions in South African higher education, 1990-2002. Journal of Studies in International Education, 8(3), 244-281. http://dx.doi. org/10.1177/1028315304265337

Mabokela, R.O. (2001). Hear our voices!: Women and the transformation of South African higher education. Journal of Negro Education, 70(3), 204-218. http:// African higher education. Journ
dx.doi.org/10.2307/3211211

May, M.S., \& Evans, A.C. (2004). Making group relations at home in South Africa. Journal of Psychology in Africa, 14(1), 29-36. http://dx.doi.org/10.4314/jpa. v14i1.30607

Menzies Lyth, I. (1990). A psychoanalytical perspective on social institutions. In E. Trist \& H. Murray (Eds.), The social engagement of social science (pp. 463-475). Trist \& H. Murray (Eds.), The social engagement of
Philadelphia: The University of Pennsylvania Press.

Miller, E.J. (1989). The "Leicester" Model: Experiential study of group and organizational processes. Occasional Paper: Tavistock Institute of Human Relations, 10.

Mouly, V.S., \& Sankaram, J.K. (2002). The enactment of envy within organisations: Insights from a New Zealand academic department. The Journal of Applied Behavioural Science, 38(10) 36-56. http://dx.doi.org/10.1177/0021886302381003

Ndebele, N.S. (1997). Creative instability: The case of the South African Higher education system. The Journal of Negro Education, 66(4), 443-448. http://dx.doi. org/10.2307/2668171

Neumann, J.E. (1999). Systems psychodynamics in the service of political organisational change. In R. French \& R. Vince (Eds.), Group relations, management, and organisation (pp. 54-69). New York: Oxford University Press.

Nkomo, M. (1990). Introduction. In M. Nkomo (Ed.), Pedagogy of domination: Toward a democratic education in South Africa (pp. 1-15). Trenton, NJ: Africa World Press, a demor.
Inc.

Nutkevitch, A. (1998). The Container and its Containment: A Meeting Space for Psychoanalytic and Open Systems Theories. Paper presented at the Annual Symposium of ISPSO, Jerusalem. Retrieved April 06, 2005, from http://www.ispso. org/Symposia/Jerusalem/1998nutkevitch.htm

Powell Pruitt, L. (2004). The Achievement (K)not: Whiteness and "Black Underachievement". In M. Fine, L. Weis, L. Powell Pruitt \& A. Burns (Eds.), Off White: Readings on race, power, and society (pp. 235-244). New York: Routledge.

Powell Pruitt, L., \& Barber, M. (2004). Savage inequalities indeed: Irrationality and urban school reform. In S. Cytrynbaum \& D.A. Noumair (Eds.), Group dynamics, organisational irrationality and social complexity: Group Relations Reader 3 (pp. 303-320). Washington, DC: A.K. Rice Institute.

Pretorius, M. (2003). An exploration of South African diversity dynamics. Published Master's dissertation, University of South Africa, Pretoria, South Africa.

Robus, D., \& Macleod, C. (2006). 'White excellence and black failure': The reproduction of racialised higher education in everyday talk. South African Journa of Psychology, 36(3), 463-480.

Ruth, D. (2000). The stories we tell and the way we tell them: An investigation into the institutional culture of the university of the North, South Africa. Accra: Association of African Universities.

Schafer, R. (2003). Insight and interpretation: The essential tools of psychoanalysis. London: Karnac Books.

Shapiro, E.R., \& Carr, A.W. (1991). Lost in familiar places: Creating new connections between the individual and society. London: Yale University Press.

Skolnick, M., \& Green, Z. (2004). The denigrated other: Diversity and group relations. In S. Cytrynbaum \& D.A. Noumair (Eds.), Group dynamics, organisational In S. Cytrynbaum \& D.A. Noumair (Eds.), Group dynamics, organisational
irrationality and social complexity: Group Relations Reader 3 (pp. 117-130). irrationality and social complexity:
Washington, DC: A.K. Rice Institute.

Starfield, J. (2002). Change, continuity and cultural studies: The development of an alternative humanities curriculum for Vista University, Soweto. International Journal of Cultural Studies, 5(4), 405-426. http://dx.doi.org/10.1177/13678779 020050040301

Stein, M. (2000). After Eden: Envy and the defences against anxiety paradigm. Human Relations, 53(2), 193-211.

Sumbulu, A., \& Boswell, G. (2003). Rapid change in a South African tertiary institution: Implications for occupational social work. Social work education, 22(5), 505-516. http://dx.doi.org/10.1080/0261547032000126443

Terre Blanche, M., \& Durrheim, K. (2002). Interpretive Methods. In M. Terre Blanche \& K. Durrheim (Eds.), Research in practice: Applied methods for social sciences (pp. 123-146). Cape Town: University of Cape Town Press.

Winburg, C. (2004). Symbolic representations of the post-apartheid university Theoria, December, 89-103. http://dx.doi.org/10.3167/004058104782267042

Young, R. (1995). Psychotic anxieties in groups and organisations. In D. Armstrong, W.G. Lawrence \& R.M. Young (Eds.), Group relations: An introduction. Retrieved April, 05, 2006, from http://human-nature.com/rmyoung/papers/paper99.html 